\title{
aniki
}

Revista Portuguesa da Imagem em Movimento

Portuguese Journal of the Moving Image

\section{Outra certa tendência do cinema português}

Filipa Rosário ${ }^{1}$

Araújo, Nelson. 2016. Cinema Português. Interseções Estéticas nas Décadas de 60 a 80 do Século XX. Lisboa: Edições 70. 284 pp.

No seu mais recente livro, Nelson Araújo, que já havia coordenado o volume Manoel de Oliveira. Análise Estética de uma Matriz Cinematográfica (2014) e é doutorado em Artes Visuais pela Faculdade de Belas Artes da Universidade de Vigo, examina obras maiores do cinema português dos anos 60,70 e 80 do século passado. Fá-lo com o objetivo de reconhecer nelas tendências formais estéticas, de certa forma ancoradas no Cinema Novo e consolidadas, por diversas vias, na chamada Escola Portuguesa.

Acto da Primavera (Manoel de Oliveira, 1963), Os Verdes Anos (Paulo Rocha, 1963), Belarmino (Fernando Lopes, 1964), O Cerco (António da Cunha Telles, 1970), O Recado (José Fonseca e Costa, 1971), A Promessa (António de Macedo, 1972), Uma Abelha na Chuva (Lopes, 1972), Jaime (António Reis e Margarida Cordeiro, 1974), Brandos Costumes (Alberto Seixas Santos, 1975), Trás-osMontes (Reis e Cordeiro, 1976), Amor de Perdição (Oliveira, 1979), A Ilha dos Amores (Rocha, 1982), Le Soulier de Satin (Oliveira, 1985), Recordações da Casa Amarela (João César Monteiro, 1989), entre tantos outros, são aqui interpretados à luz do contexto histórico e cultural do tempo da produção dos filmes e no âmbito de um quadro teórico cujas ideias mais estruturantes remontam a Theodor Adorno, Walter Benjamin e Bertolt Brecht.

Arriscando na estruturação do trabalho, o autor apresenta, nos primeiros quatro capítulos - "Metodologia Fundamentada e Suporte Teórico", "O Estado da Arte", "A Forma" e "Contextualização" -, o ponto de partida teórico, historiográfico e histórico-contextual da sua investigação. Com efeito, eles correspondem a uma segunda, e derradeira, introdução a este Cinema Português. Interseções Estéticas nas Décadas de 60 a 80 do Século XX. Nelson Araújo inicia, a partir daí, a sua reconfiguração estética daquele cinema português, partindo de uma ideia tão forte quanto interessante, apresentada no quinto capítulo "Jaime e João de Deus, as Figuras Tutelares”, e que corresponde à ideia de que as duas personagens são matriciais deste universo fílmico, assombrando-o

\footnotetext{
${ }^{1}$ Universidade de Lisboa, Faculdade de Letras, Centro de Estudos Comparatistas, 1600-214, Lisboa, Portugal.
} 
por via da resistência que as suas loucuras parecem representar. A partir desta assunção iluminadora, tudo aquilo que lhe segue concentra-se no espaço fílmico das obras que analisa: o espaço de alguma paisagem geográfica (no sexto capítulo, "O Espaço Enquanto Elemento Estético da Imagem), da mise-en-scène arquitetural e da cidade fechada (ambos no sétimo capítulo, "A Imagética da Clausura: o Espaço como Metáfora"), e da plasticidade dos rostos filmados (no oitavo capítulo, "O Rosto como Superfície Bipolar"). A análise do rosto de Teresa Menezes em Francisca (Oliveira, 1981), rosto esse que revela, no filme e também nas palavras de Agustina Bessa Luís, "uma maneira de inclinar a cabeça que parece uma predestinação para a estatuária elegíaca” (1979: 17), é, neste contexto, particularmente certeira. A fechar este percurso teórico, surge o teatro épico de Brecht, no nono capítulo, intitulado "Horizontes Brechtianos no Cinema Português", em que o distanciamento do espectador face à realidade representada promove a reflexão e o juízo crítico, por oposição ao entretenimento alienante. Nelson Araújo reconhece mecanismos internos do teatro épico de Brecht no cinema português, rematando a sua narrativa com a análise de Le Soulier de Satin e de A Ilha dos Amores em função de ideias de tempo fílmico, no décimo capítulo, de nome "O Ritmo como Construção de um Tempo Cinematográfico Reflexivo". No décimo primeiro capítulo, "Reflexões Finais", o autor resume a trajetória analítica que realizou até aqui, não só identificando as duas tendências do cinema português, mas também verificando uma unidade entre elas, concebida enquanto questionamento coletivo daquilo que Portugal demonstra ser.

Reconhecendo os tais modelos(-fantasmas) de um certo cinema nacional, Cinema Português. Interseções Estéticas nas Décadas de 60 a 80 do Século $X X$ parte, então, da análise do espaço para chegar a lógicas de tempo, constatando outras duas tendências maiores no corpus investigado - o cinema de poesia e o cinema de prosa -, que, no entanto, se ligam, segundo o autor, na sobre-importância das dimensões visual e plástica que todos estes filmes refletem.

A grande força do livro de Nelson Araújo reside no facto de mergulhar com energia num conjunto de filmes que, de formas diferentes, desafiam os seus espectadores. Trata-se de obras, na sua maioria, profundamente sofisticadas, cultas, por vezes herméticas, a exigir contextualização e descodificação. Ou seja, podem assustar. Mas são, a meu ver, os filmes que verdadeiramente formam aquilo que, à falta de melhor expressão, poderia apelidar-se de cinema clássico português, pois não só detêm a chave de compreensão da maior parte da produção nacional contemporânea, como abriram caminhos estéticos, poéticos e políticos revolucionários que efetivamente ainda não se fecharam; são pioneiros. E são clássicos no sentido em que Italo Calvino concebe os clássicos (1993): conseguem ser tão apreciados e valorizados no primeiro visionamento como nos seguintes; cada visionamento traz uma descoberta consigo; 
um clássico nunca termina de dizer aquilo que tem para dizer; um clássico influencia ou porque é inesquecível ou porque já faz parte do inconsciente colectivo ou individual; um clássico gera sempre discursos críticos sobre si mesmo, sem no entanto deixar de os repelir para longe. A lista poderia continuar.

Num estilo de escrita bastante desafiador, Nelson Araújo revolve um universo extraordinário de filmes para compreender que ideias de cinema partilham, como constroem os seus espaços, como esses espaços parecem comunicar entre si, a que tempos algumas dessas representações dão origem. Nesse sentido, Cinema Português. Interseções Estéticas nas Décadas de 60 a 80 do Século $X X$ deixa a descoberto relevantes articulações teóricas de um período áureo da história do cinema português e, por esse motivo, é um trabalho louvável e bastante útil.

\section{BIBLIOGRAFIA}

Calvino, Italo. 1993. Por que ler os Clássicos. São Paulo: Companhia das Letras.

Luís, Agustina B.. 1979. Fanny Owen. Lisboa: Guimarães. 